\title{
EXAMINING RELATIONSHIPS BETWEEN EFL STUDENTS' LEARNING STYLES, WRITING PROFICIENCY, AND SELF-ASSESSMENT
}

\author{
Andri Suherman \\ Language Centre, University of Mataram \\ E-mail: andrisuherman123@,gmail.com
}

\begin{abstract}
This research article aimed to explore the relationship between students' learning styles, writing proficiency, and self-assessment. The participants in this case study were forty Indonesian tertiary-level EFL learners. This study investigated language learning styles preferences of the participants, analyzed preferred language learning styles of the most proficient writers, and explored how the participants assess their writing ability. Multiple sources of data were collected, including questionnaires, self-assessment checklist, and students' writings. The findings revealed two main points. First, students' learning styles (Communicative, Concrete, Analytical, and Authority-Oriented) showed a strong relationship with students' writing proficiency. In this case, the most popular learning style (Communicative) was used by the majority of proficient writers. It indicated that Communicative learning style benefited students with regard to writing proficiency. Second, students writing proficiency did not relate to student's self-assessment. In this case, the most proficient writers appeared to underestimate their writing ability, meanwhile the least proficient writers seemed to overestimate their writing ability. The pedagogical implications of this study were to provide insight to EFL teachers into how students' learning styles can help them to make the necessary adaptation and changes in the instruction, and to inform EFL learners with some suggestions to carry out self-assessments to help them improve their writing performance.
\end{abstract}

Keywords: EFL learners, learning styles, writing proficiency, self-assessment

\section{A. INTRODUCTION}

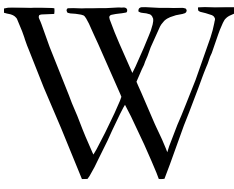

Ong and Nunan (2011) defined style as "an individual's natural, habitual, and preferred way of absorbing, processing, and retaining new information and

skills". Style was differently categorized by several researchers. Some of them

distinguished between cognitive style, sensory style, and personality style. Meanwhile, Gholami and Ahghar (2012) argued that learning style involved four main aspects of a person; (1) habitual patterns of mental functioning, (2) patterns of attitudes and interests, (3) the tendency to seek situation compatible, and (4) the tendency to apply learning strategies.

Learning styles vary for each of student in different situation (Riazi and Riasati, 2007). While some students preferred to learn by gaining information from books or newspapers, the others preferred a verbal explanation or lecture. Moreover, students differently showed their understandings, either orally or in writing and through figures, tables, or graphs. Keefe (1982) argued that learning styles referred to the individual behaviours (i.e. cognitive, emotional, and psychological) which functioned as fixed indicators of how learners understand and respond 
to the learning environment. Related to SLA, Oxford (2003) mentioned that learning styles were the general methods which learners apply to acquire a new language.

The present study exploring the relationship between writing ability and learning styles grounded from 4 main categories of learning styles (Communicative, Concrete, Analytical and Authority-Oriented) proposed by Willing (1988). In respond to this, Nunan (1999) mentioned the characteristics of the aforementioned four types of learning styles. First, Communicative style is mostly chosen by those who like a communicative or social interaction in relation to language learning. Second, Concrete is a learning style which use direct procedures for obtaining information and knowledge. Third, Analytical learning style refers to learning something by primarily analyzing the information being learnt. Fourth, Authority-Oriented learners mostly depend on the teachers' explanation.

To sum up, a considerable body of research has been carried out in relation to students learning styles and student's self-assessment with regard to writing skill. In line with these studies, the present study attempts to examine the relationship between three variables (learning styles, writing proficiency, and self-assessment) in the context of Indonesian tertiary EFL learners. It is hoped that the findings from the present study can provide insight into how students preferred learning styles influence their writing skill, and how the most and least proficient students assessed their own writing skill.

The following session is my review of related literature. In the second chapter, I present research method I used including research setting, instruments, research design, and the technique of data analysis.

\section{B. LITERATURE OF REVIEW}

This section summarizes two main aspects (learning styles and self-assessment) as the main goal of the present study, followed by the study objectives and research questions.

\section{Learning Styles}

Over the past few years, there has been a great body of research focusing on learning styles. For example, Reid (1987) conducted a study to investigate learning styles preferences for 1,300 ESL students from 3 different cultures; Korean, Japanese, and Malay. The findings revealed that the majority of these students preferred tactile and kinaesthetic learning styles. Additionally, this study found that the inherent differences (language background, cultural, and educational history) played a significant role in analyzing different types of cognitive styles. Meanwhile, Kavaliauskiene (2003) investigated 43 law major students from the University of Lithuana regarding their learning styles for ESP classes. The findings revealed 
that over $50 \%$ of the participants preferred a communicative style to help them improve their language skills. Further analysis showed that the participants primarily focused on learning English to obtain good marks. In other words, they did not prepare themselves for future English competence.

In the context of Iranian EFL classes, Riazi and Riasati (2007) analyzed students learning styles and the degree of teachers' awareness. The findings showed that the 219 participated students did not want to do individual work, but this condition was not perceived by the teachers. Furthermore, both teachers and students possessed different perception regarding vocabulary learning strategies, but both of them were aware of the essential of cultural competence in language learning. Meanwhile, language learning styles in the context of Hong Kong undergraduate learners were examined by Wong and Nunan (2011). They found that the 110 participated students showed significant different in their learning strategy, learning style, and language use. Furthermore, this study suggested that teachers should adapt their teaching practices to suit the students' learning styles, and students should be encouraged to take responsibility for their own learning.

The studies mentioned above have primarily focused on the strategy use of proficient learners while performing language skills. However, few studies have examined the language learning style used by proficient learners while performing writing tasks. This existing gap leads the present study to investigate how proficient learners use language learning styles to complete writing tasks.

\section{Self-Assessment}

Self-assessment is a kind of formative strategy in the process of assessing learners' performance. McMilan and Hearn (2008) argued that self-assessment was a tool to provide learners with an opportunity to judge their work and subsequently make improvement as they analyze discrepancies between their current activity and desired performance. As such, selfassessment enables learners and teachers assess learning since it provides clear goals and specific criteria.

Several researchers have investigated the effects of self-assessment in the context of EFL/ESL classroom. For example, Hung (2009) conducted a qualitative study by analyzing how two EFL learners utilized self-assessment while writing compositions in their electronic portfolios. The findings revealed that both of the two learners applied a variety of strategies (cognitive, meta-cognitive, and memory) in completing the writing tasks. They also applied self-assessment to judge their writing quality and to analyze their strengths and weaknesses. 
In the context of Iranian EFL learners, Javaherbakhsh (2010) explored the effects of selfassessment on learners' writing skills. The results showed that self-assessment had a significant influence on learners' writing skills. Further analysis found that self-assessment checklist benefited both teachers and learners. For teachers, they became more aware of students' strengths, weaknesses, and needs. For learners, they became more autonomous learners and more sensitive of efficient strategies for their own learning.

The studies mentioned above have primarily focused on the impact of self-assessment practice on the improvement of learners' writing ability. However, there has no study has examined whether EFL learners were able to assess their writing ability accurately. This existing gap leads the present study to investigate how accurate EFL learners assess their writing ability.

\section{Study Objectives and Research Questions}

As the gaps showed by literature review above, the present study attempts to fill the gaps and make contribution to the body of research by examining the relationship between a group of Indonesian EFL learners' language learning styles, their writing proficiency, and the accuracy of their self-assessment. In other words, the present study wants to find which learners are more proficient with regard to their writing skill, and which learners have more realistic picture of their writing skill.

Based on the aforementioned points, the present study attempts to answer three following research questions:

1. What is the most favourite English learning style of the participated students?

2. What is the most favourite English learning style of the proficient writers?

3. How do the participants assess their writing skill ability?

\section{RESEARCH METHDOS}

\section{Research Setting}

A convenient sample of 40 third-year English major students (26 females and 14 males) participated. Their age range was between 19 and 23 years old. These students were categorized as pre-intermediate EFL learners based on two reasons, (1) the students' class records gained from their writing teacher, and (2) the students' average score of $500-550$ on TOEFL-ITP. This study was conducted in an EFL writing classroom at English Education department, University of Mataram, Indonesia.

\section{Instruments}


Three instruments were employed in this study. First instrument was the Learning Styles Preferences questionnaire. This four-point Likert scale questionnaire consisted of 24 items about 4 categories of learning styles. The questionnaire was adapted from Willing (1988) with the reliability of Cronbach's Alpha 0.653. The second instrument was students writing draft. This writing draft was used to determine students writing proficiency and to match them with students learning styles. The last instrument was a self-assessment scale for writing. This scale consisted of 30 items about several aspects of writing. The participants were required to assess their ability on the writing task by giving a grade from 0 (zero) to 10 (ten) on each statement. The scale was adapted from essay scoring rubric by Paulus (1999).

\section{Research Design}

At first, all the participants completed the Learning Styles Preference questionnaire. After that, they were asked to write a composition of 150-200 words on a chosen IELTS exam writing topic. Last, they assessed their performance on this writing task using the selfassessment checklist provided.

\section{Data Analysis}

The data gained from the three instruments was analyzed quantitatively by calculating the pattern of descriptive statistics, namely Mean (M) and Standard Deviation (SD).

\section{FINDINGS AND DISCUSION}

\section{What is the most favourite English learning style of the participated students?}

To identify the English learning style mostly liked by the participants, descriptive statistics, including Mean (M) and Standard Deviation (SD), were computed. The learning style which showed the highest value was considered as the most favourite learning style for the participants.

Table 1. Descriptive statistics for English learning style.

\begin{tabular}{|c|c|c|c|}
\hline $\begin{array}{c}\text { English } \\
\text { learning style }\end{array}$ & Participants (N) & $\begin{array}{c}\text { Mean } \\
(\mathrm{M})\end{array}$ & $\begin{array}{c}\text { Standard Deviation } \\
(\mathrm{SD})\end{array}$ \\
\hline Communicative & 40 & 3.23 & 0.35 \\
\hline Concrete & 40 & 3.09 & 0.23 \\
\hline Analytical & 40 & 3.13 & 0.18 \\
\hline Authority-Oriented & 40 & 3.03 & 0.29 \\
\hline
\end{tabular}


Volume 4, Number 2, December 2018

The table above showed that Communicative was the most popular English learning style among the participated students. It was indicated by its highest Mean (M) value of 3.23 and Standard Deviation (SD) value of 0.35 . In other words, the majority of the participants preferred Communicative style in learning English.

This finding seemed to be similar with that of previous studies. For example, Sahragard and Mallahi (2014) found that the 30 Iranian students who participated in the study preferred Communicative style in learning English. In the context of Hong Kong tertiary-level EFL learners, the study by Ho (1999) found that most of the participants preferred Communicative learning style. Nevertheless, several studies revealed different results. For example, Willing (1988) found that 517 adult ESL learners in Australia favoured Analytical and Concrete learning style. Meanwhile, in the context of EFL learners in Taipei, Liu (2008) reported that AuthorityOriented learning style was the most popular among the participants as indicated by its highest Mean (M) and Standard Deviation (SD) score.

\section{What is the most favourite English learning style of the proficient writers?}

Based on the score gained from students' draft, the researcher classified the students into three categories; beginner (score from 0 to 10), intermediate (score from 11 to 20), and advanced (score from 21 to 30). Those who belong to advanced category were labelled as the most proficient writers. In this case, there were only 9 students who belong to advanced category. To identify the English learning style mostly liked by these proficient writers, the Mean (M) score in each type of learning style was calculated. The learning style which showed the highest Mean (M) score was considered as the most favourite learning style for the proficient writers.

Table 2. The Mean (M) scores for the proficient writers in each type of English learning style.

\begin{tabular}{|c|c|c|c|c|}
\hline $\begin{array}{c}\text { Proficient } \\
\text { writers }\end{array}$ & Communicative & Concrete & Analytical & $\begin{array}{c}\text { Authority- } \\
\text { Oriented }\end{array}$ \\
\hline 1 & 3.24 & 3.33 & 3.15 & 2.65 \\
\hline 2 & 3.32 & 3.29 & 2.80 & 3.17 \\
\hline 3 & 3.23 & 3.25 & 3.32 & 2.70 \\
\hline 4 & 3.24 & 3.22 & 3.15 & 2.65 \\
\hline 5 & 3.27 & 2.91 & 2.70 & 3.15 \\
\hline 6 & 3.17 & 2.70 & 3.25 & 3.15 \\
\hline 7 & 3.67 & 3.27 & 3.25 & 2.49 \\
\hline
\end{tabular}




\begin{tabular}{|l|l|l|l|l|}
\hline 8 & 3.23 & 3.17 & 2.50 & 2.70 \\
\hline 9 & 3.25 & 3.15 & 2.49 & 2.83 \\
\hline
\end{tabular}

The table above indicated that 6 proficient writers $(2,4,5,7,8$, and 9$)$ appeared to favour Communicative learning style. Meanwhile, the other 3 proficient writers seemed to prefer different learning styles; writer 1 preferred Concrete, writer 3 and 6 preferred Analytical. To conclude, Communicative was the most popular English learning style among the majority of the most proficient writers in the current study. This finding was similar to that of Sahragard and Mallahi (2014). They found that among the 7 of proficient writers, most of them (4 writers) favoured Communicative learning style.

The finding above suggested that communicative tasks should be provided more especially in writing courses because they can lead to better academic writing achievement. However, Ho (1999) argued that it is necessary to include learning tasks which suit all learner types to meet their needs. Therefore, Kinsella (1996) mentioned that the percentage of the task types should be adjusted to different types of learners so as to accommodate them to perform the tasks.

\section{How do the participants assess their writing skill ability?}

Based on the data gained from self-assessment scale for writing, it was found that the top students (high proficient writers) seemed to underestimate their writing ability. They also scored different aspects of their writing skill lower than their actual writing ability. On the contrary, the low students (less proficiency writers) appeared to score different aspects of their writing skill higher than their actual writing ability. This finding supported what Birckbicler, Corl, and Devil (1993) argued. They mentioned that although learners can accurately assess their abilities or achievements, this self-assessment practice can be overestimated. Moreover, Heilenmen (1990) reported that learners proficiency level does matter with self-assessment accuracy, with higher proficiency ESL students participated in his study underestimated their abilities.

The accuracy of learners' self-assessment had been discussed by several researchers in the field of ELT. For example, Ross (1998) highlighted that there was variation in the accuracy of learners' self-assessment. Similarly, Brantmeier, Vanderplank, and Strube (2012) mentioned two main things which influenced the accuracy of self-assessment; (1) the language skill being assessed, and (2) the materials being tested. In different educational context, Oscarson (1989) reported the same finding with the current study where the top students participated in his 
study appeared to underestimate their ability. However, different finding was revealed by Rasch (1979) where the participated ESL students more accurately assess their speaking ability than their writing ability.

\section{E. CONCLUSION}

This study aimed to investigate the relationship between students' learning styles, writing proficiency, and self-assessment. The findings showed that Communicative was the most popular English learning style among the students, followed by three others styles, called Concrete, Analytical, and Authority-Oriented. In addition, based on the students' writing scores, nine students were considered the most proficient writers, and most of them had applied Communicative learning style to help them organize their writings. Furthermore, the most proficient writers, compared to the self-assessment performance of the least proficient writers, appeared to underestimate their writing ability.

Several limitations occurred in this study such as small sample of data and small number of participants. Future research may apply the same methods on a larger scale, or in different educational contexts. Despite these limitations, several implications can be clearly seen. For example, this study provided insight to EFL teachers into how students' learning styles can help them to make the necessary adaptation and changes in the instruction, and to inform EFL learners with some suggestions to carry out self-assessments to help them improve their writing performance.

\section{REFERENCES:}

Birckbichler, D., Corl, K., \& Deville, C., (1993). The dynamics of language program testing: Implications for articulation and program revision. In The Dynamics of Language Program Direction. Boston, MA: Heinle \& Heinle.

Brantmeier, C.,Vanderplank, R., \& Strube, M.(2012).What about me? Individual selfassessment by skill and level of language instruction. System, 40 (1), 144-160.

Heilenman, L. K. (1990). Self-assessment of second language ability: The role of response effects. Language Testing , 7(2), 174-201.

Ho, B. (1999). Learning style preferences of students in learning English. (Online) Retrieved 20 June 2012 from http://sunzi1.lib.hku.hk/hkjo/view/10/1000157.pdf

Hung, Sh. T. (2009). Promoting self-assessment strategies: An electronic portfolio approach. Asian EFL Journal Quarterly, 2, 129-146.

Javaherbakhsh, M. R. (2010). The impact of self-assessment on Iranian EFL learners' writing skill. English Language Teaching, 3(2), 213-216. 
Keefe, J. W. (Ed.). (1982). Student learning styles and brain behaviour: Programs, instrumentation, research. Reston, VA: National Association of Secondary School Principals.

Kinsella, K. (1996). Designing group work that supports and enhances diverse classroom work styles. TESOL Journal, 6(1), 24-31.

Kavaliauskiene, G. (2003). English for specific purposes: Learners' preferences and attitudes. Journal of Language and Learning, 1(1), 14-23.

Liu, H. J. (2008). A study of the interrelationship between listening strategy use, listening proficiency levels, and learning style. RARECLS, 5, 84-104.

Nunan, D. (1999). Second Language Teaching and Learning. Boston: Heinle \& Heinle.

Oscarson, M. (1989). Self-assessment of language proficiency: Rationale and applications. Language Testing, 6, 1-13.

Oxford, R. L. (2003). Language learning styles and strategies: Concepts and relationships. IRAL, 41(4), 271-278.

Paulus, T. M. (1999). The effect of peer and teacher feedback on student writing. Journal of Second Language Writing, 8, 265-289.

Rasch, G. (1979). Probabilistic Models for Some Intelligence and Achievement Tests. Danish Institute for Educational Research, Copenhagen.

Reid, J. M., (1987). The learning style preferences of ESL students. TESOL Quarterly, 21 (1), 87-111.

Riazi, M., \& Riasati. M. J. (2007). Language learning style preferences: A case study of Shiraz EFL Institutes. The Asian EFL Journal Quarterly, 9 (1), 97-125.

Ross, S. (1998). Self-assessment in second language testing: A meta-analysis and analysis of experimental factors. Language Testing, 15(1), 1-19.

Willing, K. (1988). Learning styles in adult migrant education. Australia: NCRC Research Series.

Wong, L., \& Nunan, D. (2011). The learning styles and strategies of effective language learners. System, 39, 144-163. 